\title{
PENGEMBANGAN INSTRUMEN TES DIAGNOSTIK BERBENTUK URAIAN UNTUK MENGIDENTIFIKASI PEMAHAMAN KONSEP MATEMATIKA WAJIB SISWA MAN 1 MAKASSAR
}

\author{
A. Sriyanti ${ }^{1}$, Sitti Mania ${ }^{2}$, Nurul Hairani $A^{\mathbf{3}}$ \\ Universitas Islam Negeri Alauddin Makassar ${ }^{1,2,3}$ \\ pos-el: a.sriyanti@uin-alauddin.ac.id ${ }^{1}$, sittimania@yahoo.com ${ }^{2}$, nurulhairani60@gmail.com ${ }^{3}$
}

\begin{abstract}
ABSTRAK
Penelitian ini bertujuan menghasilkan sebuah instrumen tes diagnostik untuk mengidentifikasi tingkat pemahaman konsep matematika siswa yang berbentuk uraian. Jenis penelitian yang digunakan adalah Research and Development (R\&D). Model pengembangan yang digunakan adalah model Plomp yang terdiri dari 4 tahapan yaitu: (1) tahap pengkajian awal (preliminary investigation phase), (2) tahap perancangan (desain phase), (3) tahap realisasi/konstruksi (realization/construction phase), dan (4) tahap tes, evaluasi dan revisi (test, evaluation and revision phase). Subjek uji coba dalam penelitian ini adalah siswa kelas XI MAN 1 Makassar yang berjumlah 38 orang siswa. Hasil uji coba yang dilakukan, diperoleh bahwa instrumen tes diagnostik berbentuk uraian ini sudah dikatakan valid karena hasil CVR yang diperoleh adalah 1 dan telah memenuhi kriteria yaitu $\geq 0,99$ dan hasil CVI yang diperoleh adalah 1 dengan kategori sangat sesuai atau berada pada kisaran 0,68-1,00. Hasil uji reliabilitas yang diperoleh adalah 0,75 dengan kategori tinggi dan berada pada kisaran $0,60<\mathrm{r}_{11}<0,80$. Instrumen tes diagnostik berbentuk uraian memiliki tingkat kesukaran dengan hasil rata-rata 0,56 dengan kategori sedang yaitu berada pada kisaran 0,31-0,70. Instrumen tes diagnostik berbentuk uraian memiliki daya pembeda dengan rata-rata 0,34 dengan kategori cukup dan berada pada kisaran $0,20<\mathrm{Dp} \leq 0,40$. Hasil data tes diagnostik berbentuk uraian untuk mengidentifikasi pemahaman konsep siswa, dapat diketahui bahwa jumlah siswa yang termasuk dalam kategori paham konsep 29,74\%, persentase siswa yang mengalami miskonsepsi sebesar $32,11 \%$ dan persentase siswa yang tidak paham konsep sebesar $38,16 \%$.
\end{abstract}

Kata kunci : pengembangan instrumen tes diagnostik, tes berbentuk uraian, dan pemahaman konsep matematika

\section{ABSTRACT}

This study aims to produce a diagnostic test instrument to identify the level of understanding of students' mathematical concepts in the form of descriptions. The type of research used is Research and Development $(R \& D)$. The development model used is the Plomp model which consists of 4 stages, namely: (1) the initial assessment phase (preliminary investigation phase), (2) the design stage (design phase), (3) the realization phase / construction phase, and (4) the stages of testing, evaluation and revision (test, evaluation and revision phase). The subjects of the trial in this study were the eleventh grade students of MAN 1 Makassar, which amounted to 38 students. The results of the trial conducted, it was found that the diagnostic test instrument in the form of this description was said to be valid because the $C V R$ results obtained were 1 and had met the criteria of $\geq 0.99$ and the CVI results obtained were 1 with a very appropriate category or in the range 0, 68-1.00. The reliability test results obtained are 0.75 with a high category and are in the range of $0.60<r 11<0.80$. The diagnostic test instrument in the form of description has a level of difficulty with an average result of 0.56 with a moderate category which is in the range of 0.31-0.70. The diagnostic test instrument in the form of description has a differentiating power with an average of 0.34 with sufficient 
categories and in the range of $0.20<D p 0.40$. The results of diagnostic test data in the form of a description to identify students' conceptual understanding, it can be seen that the number of students included in the conceptual understanding category is $29.74 \%$, the percentage of students who experience misconceptions is $32.11 \%$ and the percentage of students who do not understand the concept is $38.16 \%$.

Keywords : development of diagnostic test instruments, tests in the form of descriptions and understanding of mathematical concepts

\section{PENDAHULUAN}

Pendidikan merupakan hal utama yang menjadi salah satu faktor terpenting dalam menjalani hidup bermasyarakat. Sebab pendidikan bagi kehidupan umat manusia merupakan kebutuhan mutlak yang harus dipenuhi sepanjang hayat. Tanpa pendidikan sama sekali mustahil suatu kelompok manusia dapat hidup berkembang sejalan dengan aspirasi/cita-cita untuk maju, sejahtera dan bahagia menurut konsep pandangan hidup mereka.

Ali Hamzah (2014: 2-3) menjelaskan bahwa kemajuan suatu bangsa ditentukan dari bagaimana perkembangan pendidikan bagi anak bangsa itu. Kemajuan dalam satuan waktu jangka panjang akan dapat memprediksi kualitas bangsa pada sekian puluh tahun ke depan. Hal ini menunjukkan keberadaan pendidikan demikian penting.

Sedangkan Natalia Rosalina Rawa (2016: 2) mengatakan bahwa seiring berkembangnya pendidikan di Indonesia yang semakin maju dan semakin banyak perubahan yang signifikan maka sampai pada saat ini Indonesia masih berpegang pada kurikulum 2013 sebagai landasan untuk mencerdaskan bangsa salah satunya dalam pelajaran matematika dimana siswa dituntut aktif dalam belajar. Pembelajaran matematika dalam Kurikulum 2013 menekankan pada dimensi pedagogik modern dalam pembelajaran, yaitu menggunakan pendekatan ilmiah (scientific approach) meliputi mengamati, menanya, menalar, mencoba, membentuk jejaring untuk semua pelajaran. Selain itu, dalam kurikulum 2013 siswa dimotivasi untuk mengecek informasi baru dengan yang sudah ada dalam ingatan. Hal ini menyiratkan bahwa kurikulum matematika menekankan pada dimensi pedagogik dalam hal pemahaman konsep. Menurut Angga Murizal (2012: 19) salah satu aspek yang terkandung dalam pembelajaran matematika adalah konsep. "Jika diibaratkan, konsepkonsep merupakan batu-batu pembangunan dalam berpikir". Akan sangat sulit bagi siswa untuk menuju ke proses pembelajaran yang lebih tinggi jika belum memahami konsep. Oleh karena itu, kemampuan pemahaman konsep matematis adalah salah satu tujuan penting dalam pembelajaran matematika. Sebagai fasilitator di dalam pembelajaran, guru semestinya memiliki pandangan bahwa materimateri yang diajarkan kepada siswa bukan hanya sebagai hafalan, namun lebih dari itu, yaitu memahami konsep yang diberikan. Dengan memahami, siswa dapat lebih mengerti akan konsep materi pelajaran itu sendiri, bukan hanya sekedar dihafal.

Pemahaman konsep pada matematika sangat penting, karena 
matematika sangat menekankan konsep dalam berpikir dan bernalar. Menurut Bloom paham itu tidak terbatas hanya pada kemampuan mengingat sebuah fakta akan tetapi pemahaman memiliki makna yang lebih luas yaitu kemampuan dalam menangkap sebuah makna atau arti dari suatu konsep yang telah disajikan. Untuk mengetahui pengetahuan dan pemahaman siswa terhadap konsep matematika menurut NCTM dapat dilihat dari indikator kemampuan siswa dalam:
a. Mendefinisikan konsep secara verbal dan tulisan
b. Mengidentifikasi dan membuat contoh dan bukan contoh
c. Menggunakan model, diagram dan simbol-simbol untuk merepresentasikan suatu konsep

d. Mengubah suatu bentuk representasi ke bentuk lainnya

e. Mengenal berbagai makna dan interpretasi konsep

f. Mengidentifikasi sifat-sifat suatu konsep dan mengenal syarat yang menentukan suatu konsep

g. Membandingkan dan membedakan konsep-konsep.

Pemahaman akan konsep memang sangat dibutuhkan terutama pada pelajaran matematika, dimana siswa dituntut untuk paham dan mengerti benar apa yang telah diajarkan, namun pada keyataannya masih banyak siswa yang tidak mengerti terhadap materi yang diajarkan. Selain berbagai bentuk permasalahan yang dihadapi, kesalahan yang paling fatal terjadi dalam pelajaran matematika adalah miskonsepsi atau kesalahan dalam memahami konsep. Miskonsepsi adalah pemahaman konsep yang bertentangan dengan konsep ilmiah yang dipengaruhi oleh pengalaman siswa. Miskonsepsi itu sendiri tidak boleh dianggap remeh karena kemungkinan penyebarannya akan cepat, misalnya pada saat siswa belajar kelompok atau sedang berdiskusi di kelas, selain itu miskonsepsi akan semakin menyebar seperti efek yang beruntun jika siswa kurang menguasai konsep dasar.

Berbagai permasalahan tersebut dapat terselesaikan apabila peran para pendidik dapat berjalan dengan baik dan memperhatikan berbagai aspek yang melatarbelakangi siswa gagal dalam memahami konsep. Para pendidik tidak hanya memberikan materi saja melainkan harus lebih bijaksana dalam menghadapi siswa. Menurut Suwarto (2013) para pendidik tidak hanya bertugas mengajar, tetapi harus dapat menciptakan situasi dan kondisi proses pembelajaran yang efektif, efisien, relevan, supaya anak didiknya dapat belajar dengan baik, dapat mengembangkan bakat dan kepandaiannya seoptimal mungkin, dan menunjukkan pola-pola yang sesuai dengan tujuan yang telah diterapkan. Untuk itu agar dapat mengetahui kondisi siswa yang sebenarnya diperlukan sebuah tes yang dapat mengidintifikasi penyakit yang dialami siswa agar para pendidik dapat melihat sejauh mana konsep yang diajarkan sampai kepada siswa, tes yang dimaksud adalah tes diagnostik.

Tes diagnostik adalah tes yang dilaksanakan untuk menentukan secara tepat. Jenis kesukaran yang dihadapi oleh para peserta didik dalam suatu pelajaran tertentu. Dengan diketahuinya jenis-jenis kesukaran yang dihadapi oleh peserta didik itu maka lebih lanjut akan dapat dicarikan upaya berupa 
pengobatan yang tepat. Penilaian diagnostik yaitu untuk mengetahui masalah-masalah yang diderita atau mengganggu peserta didik, artinya ada banyak masalah yang dihadapi peserta didik yang akan kami cari tahu solusinya dengan memberikan beberapa bentuk soal berupa tes uraian yang kemudian akan ada solusi yang kita temukan dari hasil diagnosa tersebut. Tujuan penilaian diagnostik yaitu, untuk membantu kesulitan atau mengatasi hambatan yang dialami peserta didik waktu mengikuti kegiatan pembelajaran pada suatu bidang studi atau keseluruhan program pembelajaran.

Menurut Ali Hamzah (2014:15), tes uraian adalah tes yang jawabannya diberikan dalam bentuk menuliskan pendapat berdasarkan pengetahuan yang dimiliki. Pengetahuan yang diukur dengan tes uraian merupakan pengetahuan kognitif tingkat tinggi.

Tes uraian merupakan tes yang efektif digunakan untuk menguji kemampuan siswa dalam suatu mata pelajaran. Namun, dalam hal penskoranya tes uraian cenderung berbeda-beda apabila dilakukan oleh orang yang berbeda pula, lain halnya dengan tes yang berbentuk pilihan ganda pemberian skor tidak akan bervariasi karena hanya menggunakan kriteria jawaban benar dan salah, jika benar bernilai 1 dan jika salah maka skor 0. Kelebihan tes uraian itu sendiri adalah kita mampu melihat sejauh mana siswa memahami pelajarannya dari jawaban yang mereka kerjakan serta siswa dapat lebih bebas dalam menjawab soal atau tes yang diberikan.

Dengan berbagai kelebihan dan kegunaan yang didapatkan pada tes uraian, maka tes yang digunakan untuk mendiagnosa pemahaman konsep siswa adalah tes diagnostik berbentuk uraian. Dalam menyusun tes diagnostik perlu diperhatikan tahapan dalam penyusunan tes diagnostik.

Menurut Yunita (2006) bahwa dalam setiap penyusunan tes diagnostik dilakukan melalui beberapa tahap. Tahapan penyusunan tes diagnostik yaitu penentuan tujuan tes, penulisan soal, penelaahan soal (review dan revisi soal), uji coba soal, analisis, perakitan soal menjadi perangkat tes:

Berdasarkan pengalaman waktu Praktek Pengalaman Lapangan (PPL) di MAN 1 Makassar dan hasil wawancara pada salah satu guru mata pelajaran matematika mengatakan bahwa belum pernah melakukan tes diagnostik sebelumnya dan hampir semua materi pada pelajaran matematika, siswa mengalami kesulitan dalam memahami materi, banyak pula yang terkadang ditemui siswa salah memahami pelajaran yang diberikan sehingga banyak terjadi miskonsepsi, hal ini dapat dibuktikan dengan nilai siswa pada kelas itu masih banyak yang di bawah Kriteria Ketuntasan Minimal (KKM) dengan KKM : 75, serta terlihat dari kecenderungan siswa yang tidak memperhatikan pelajaran dan cenderung pasif dalam kelas, guru di sekolah tersebut juga belum menerapkan tes diagnostik untuk siswa sehingga hanya terpaku pada nilai dan hasil serta hanya sekedar untuk mengejar KKM yang terlampau tinggi tanpa memperhatikan pemahaman konsep siswa itu sendiri.

Oleh karena itu berdasarkan beberapa penelitian yang dilakukan oleh Rahayu (2015), Sunismi 2012), Mutmainnah (2018), Mania (2018), 
membuktikan bahwa tes diagnostik memang dapat mendiagnosa miskonsepsi dan pemahaman konsep siswa siswa, Oleh karena itu, untuk mendiagnosa dan meminimalisir miskonsepsi siswa terhadap mata pelajaran matematika maka perlu dilaksanakan sebuah tes untuk mendiagnosa sejauh mana pemahaman siswa pada materi tersebut. Dalam hal ini tes yang akan dilakukan yaitu tes uraian untuk mengukur sejauh mana pemahaman siswa, sehingga penelitian ini sangat penting untuk dilaksanakan. Penelitian tes diagnostik ini juga jarang dilakukan di sekolah sebab guru hanya membuat soal untuk melihat hasil belajar berupa nilai, padahal banyak siswa yang merasa kesulitan pada pelajaran matematika.

Berdasarkan uraian di atas peneliti tertarik untuk melakukan penelitian dengan judul "Pengembangan Instrumen Tes Diagnostik Berbentuk Uraian untuk Mengidentifikasi Pemahaman Konsep Materi Matematika Wajib Siswa MAN 1 Makassar" yang sesuai kurikulum 2013. Pengembangan instrumen tes diharapkan dapat meningkatkan pemahaman siswa terhadap materi tersebut.

\section{METODE PENELITIAN}

Penelitian ini merupakan penelitian dan pengembangan (Research and Development) yang bertujuan untuk mengembangkan instrumen tes berbentuk uraian untuk mendiagnosa pemahaman konsep matematis siswa yang valid dan reliabel dalam pembelajaran matematika. Model pengembangan yang digunakan adalah model Plomp yang terdiri dari lima tahapan, tetapi penelitian ini hanya terbatas pada tahap keempat saja karena pertimbangan waktu dan biaya yang sangat besar. Tahapan tersebut adalah tahap pengkajian awal (preliminary investigation phase), tahap perancangan (design phase), tahap realisasi/ konstruksi (realization/ construction phase), dan tahap tes, evaluasi dan revisi (test, evaluation and revision phase). Berikut merupakan prosedur pengembangan yang dilakukan.

Hasil penelitian instrumen tes berbentuk uraian ini direncanakan dan diterapkan terbatas/skala kecil di kelas XI MIA 1 MAN 1 Makassar. Subjek dalam penelitian ini adalah butir-butir tes uraian untuk mengukur kemampuan pemahaman konsep siswa pada mata pelajaran matematika kelas XI SMA. Teknik pengumpulan data terdiri dari tes, angket. Instrumen pengumpulan data berupa instrumen tes, lembar validasi dan angket. Teknik analisis data terdiri dari validasi instrumen tes diagnostik pilihan ganda dua tingkat, analisis angket respon siswa, uji reliabilitas, analisis tingkat kesukaran, analisis daya pembeda, analisis efektivitas opsi dan analisis tingkat pemahaman konsep matematika siswa.

\section{HASIL DAN PEMBAHASAN}

\subsection{Deskripsi Hasil Tahap Penelitian.}

\subsubsection{Tahap Pengkajian Awal (Preliminary Investigation Phase)}

Pada tahap ini kegiatan yang dilakukan adalah menganalisis informasi yang diperoleh dari guru mata pelajaran matematika MAN 1 Makassar melalui wawancara, serta mengumpulkan berbagai macam referensi yang berhubungan dengan tes diagnostik berbentuk uraian. 


\subsubsection{Tahap Perancangan (Desain Phase)}

Pada tahap ini, peneliti mendesain produk berupa instrumen tes soal uraian. Mendesain sebuah instrumen tes perlu ditentukan terlebih dahulu adalah spesifikasi tes yang meliputi tujuan, kisi-kisi, bentuk dan panjang tes. Rancangan awal ini untuk menghasilkan produk awal pengembangan instrumen tes untuk mengukur kemampuan pemahaman konsep matematika wajib siswa kelas X SMA berupa instrumen tes diagnostik berbentuk uraian. Subjek pada penelitian ini adalah kelas XI MIA 1 MAN 1 Makassar yang telah mempelajari materi yang akan diujicobakan dengan jumlah siswa sebanyak 38 orang.

\subsubsection{Tahap Realisasi/Konstruksi} (Realization/Construction Phase)

Pada tahap ini dibuat prototype, yaitu rancangan utama yang berdasarkan pada rancangan awal. Masing-masing prototype fokus pada tiga karakteristik yaitu: konten, konstruk dan bahasa.

\subsubsection{Tahap Tes, Evaluasi dan Revisi (Test, Evaluation and Revision Phase)}

\subsubsection{Validasi Instrumen Tes}

Validasi desain instrumen tes merupakan proses kegiatan untuk menilai apakah rancangan produk, dalam hal ini insrumen tes diagnostik berbentuk uraian berupa materi dan kisi-kisi sudah layak dan sesuai atau belum. Kegiatan validasi desain dilakukan dengan meminta beberapa dosen yang ahli di bidang pengembangan instrumen tes dan ahli materi matematika untuk menilai atau memberikan judgment instrumen yang berupa kisi-kisi tes, soal tes dan materi pembelajaran yang berkaitan yang dibuat oleh peneliti.

Validasi instrumen dilakukan dengan cara memberikan lembar validasi instrumen kisi-kisi tes, soal tes, kriteria jawaban tes, kepada validator yang terdiri atas dua dosen matematika dan satu guru matematika MAN 1 Makassar

\subsubsection{Uji coba terbatas}

Uji coba pada tahap ini produk yang telah direvisi diuji cobakan kepada siswa kelas XI MIA 2 MAN 1 Makassar yang menjadi subjek uji coba. Uji coba terbatas ini dilakukan pada tanggal 18 september 2018, yang terdiri dari 21 butir soal tes dengan waktu pelaksanaan tes yaitu 90 menit. Selanjutnya data yang diperoleh dari uji coba tahap ini dianalisis reliabilitas, tingkat kesukaran, dan daya pembedanya. Setelah dianalisis maka selanjutnya dilanjutkan ke uji coba lapangan.

\subsubsection{Uji coba lapangan}

Setelah melakukan uji coba terbatas maka dari hasil revisi soal kembali dan didapatkan dari 21 butir soal tes direvisi menjadi 10 butir soal tes yang menjadi produk instrumen tes diagnostik berbentuk uraian. Soal ini kemudian diujikan kepada siswa kelas XI MIA 1 MAN 1 Makassar yang menjadi subjek penelitian. Waktu yang digunakan dalam melaksanakan tes ini adalah $2 \times 45$ menit atau 90 menit, dengan jumlah siswa sebanyak 38 orang.

\subsubsection{Hasil Pengembangan Instrumen Tes Diagnostik untuk Mengidentifikasi Tingkat Pemahaman Konsep Siswa \\ 3.1.5.1 Validasi Instrumen Tes Diagnostik Berbentuk Uraian}


Validasi instrumen tes diagnostik berbentuk uraian menggunakan dua metode yaitu: metode Content Validaty Ratio (CVR) dan Content Validaty Index (CVI). Pada tahap validasi, Validator atau Expert diminta untuk memberikan penilaian terhadap semua instrumen tes yang dikembangkan. Hasil dari analisis validasi menunjukkan bahwa dari 10 butir soal memiliki hasil CVR dan CVI sebesar 1. Sehingga nilai CVR > 0,99 dan berdasarkan kriteria CVI dari 10 butir soal tersebut termasuk kedalam kategori sangat sesuai.

\subsubsection{Analisis Angket siswa}

Sesuai hasil persentase dari 6 item pernyataan dengan kriteria yang telah ditetapkan dan berdasarkan hasil analisis pada angket respon siswa pada instrumen tes diagnostik berbentuk uraian pada uji coba lapangan diperoleh rata-rata respon positif siswa adalah $84,2 \%$ dan rata-rata respon negatif siswa adalah $15,8 \%$.

\subsubsection{Uji Reliabilitas Instrumen Tes Diagnostik Berbentuk Uraian}

Berdasarkan hasil uji reliabilitas pada program SPSS versi 20 menunjukkan nilai reliabilitas instrumen tes diagnostik berbentuk uraian adalah 0,754 dengan intrpretasi tinggi. Hal ini menjukkan bahwa instrumen dapat dikatakan reliabel.

\subsubsection{Tingkat kesukaran Instrumen \\ Tes Diagnostik Berbentuk Uraian}

Berdasarkan hasil analisis tingkat kesukaran bahwa dari 10 butir soal, sebagian besar berada pada kategori sedang karena dapat dilihat bahwa sebanyak 6 butir soal berada pada kategori ini. Soal yang termasuk kategori sukar sebanyak 1 butir. Soal yang termasuk kategori mudah sebanyak 3 butir. Dan tidak terdapat butir soal yang berkategori sangat sukar maupun sangat mudah. Maka rata-rata tingkat kesukaran soal berada pada kategori sedang yaitu 0,56.

\subsubsection{Daya Pembeda Instrumen Tes Diagnostik Berbentuk Uraian}

Berdasarkan hasil analisis daya pembeda instrumen tes diagnostik berbentuk uraian menunjukkan bahwa daya pembeda butir soal tes diagnostik berbentuk uraian yakni sebanyak 2 butir soal memiliki daya pembeda jelek, 3 butir soal memiliki daya pembeda cukup, 3 butir atau memiliki daya pembeda baik dan tidak ada soal yang memiliki daya pembeda untuk kategori sangat jelek dan sangat baik. Dengan rata-rata daya pembeda butir soal yaitu 0,34 yang berada pada kategori cukup. Dengan kata lain soal tes diagnostik berbentuk uraian cukup dapat membedakan peserta didik yang berkemampuan tinggi dengan peserta didik berkemampuan rendah.

\subsubsection{Analisis Data Tingkat Pemahaman Siswa}

Berdasarkan jawaban dari tes yang dilakukan oleh 38 siswa, dipilih beberapa jawaban peserta tes karena kesalahan miskonsepsi, tidak paham konsep dan paham konsepnya. Peserta tes yang dipilih diberikan inisial P1, P2, P3 dan P4. Beberapa kesalahan yang dilakukan peserta tes adalah kesalahan memahami konsep nilai mutlak, kesalahan pemahaman konsep pada fungsi dan tidak memahami konsep pada pertidaksamaan nilai mutlak, pecahan dan irasional.

a. Kesalahan pemahaman konsep pada saat menyelesaiakan langkah terakhir pada materi fungsi dapat dilihat pada gambar 1. 


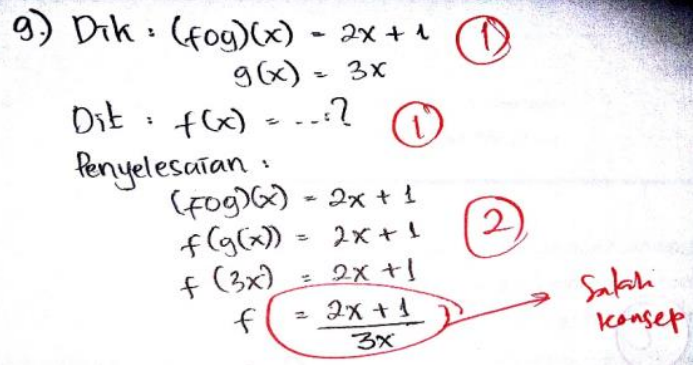

Gambar 1. Jawaban tes diagnostik P1 Nomor 9

Berdasarkan gambar 1 dapat dikatakan P1 masih belum memahami konsep dikarenakan pada langkah ketiga atau pada tahap penyelesaian P1 belum bisa menyelesaikan soal secara benar yaitu pada fungsi $g(x)$ seharusnya P1 mengubah ke bentuk invers sehingga menjadi $\frac{x}{3} \quad$ kemudian baru mensubtitusikannya pada fungsi $(f \circ g)(x)$

b. Kesalahan pemahaman konsep dalam menentukan sifat nilai mutlak dapat dilihat pada gambar 2:

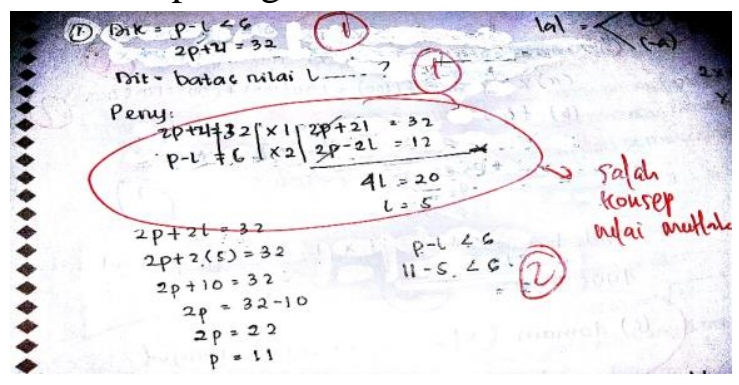

Gambar 2.Jawaban tes diagnostik P2 Nomor 1

Berdasarkan gambar 2 P2 bisa dikatakan mengalami miskonsepsi pada langkah ketiga atau langkah penyelesaian soal yang telah dikerjakan, disini P2 menggunakan konsep penyelesaian program linear yaitu metode eliminasi dalam menyelesaikan soal padahal seharusnya P2 menggunakan sifat nilai mutlak untuk menyelesaikannya.

c. Paham konsep pada materi program linear dapat dilihat pada gambar 3:

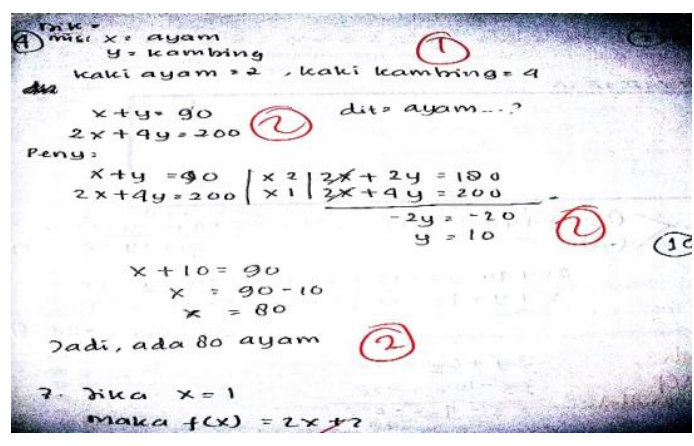

Gambar 3. Jawaban tes diagnostik P1 Nomor 4

Berdasarkan gambar sudah dapat dikatakan bahwa P1 sudah memahami konsep pada materi program linear yaitu Sistem Persamaan Linear Dua Variabel (SPLDV), karena setiap langkah yang dikerjakan oleh P1 sudah benar dan memenuhi aspek pemahaman konsep yang diinginkan, yaitu siswa dapat mendfinisikan konsep secara verbal dan tulisan, mengubah suatu bentuk representasi ke bentuk lainnya, mengidentifikasi sifat-sifat suatu konsep dan mengenal syarat yang menentukan suatu konsep serta mengenal berbagai makna dan interpretasi konsep.

d. Paham konsep pada materi program linear (SPLTV) dapat dilihat pada gambar 4:

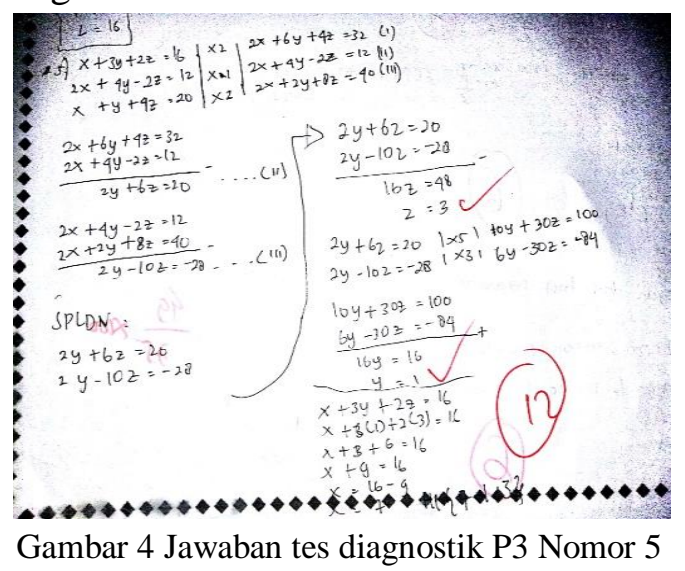

Berdasarkan gambar 4 jawaban P3 sudah dapat dikaakan paham konsep dilihat dari langkah pengerjaannya dalam menyelesaikan Sistem Persamaan Linear Tiga Variabel (SPLTV) sudah 
benar dan sesuai dengan syarat aspek pemahaman konsep yaitu mendevinisikan konsep secara verbal dan tulisan, mengubah suatu bentuk representasi ke bentuk lainnya dan mengenal berbagai makna dan interpretasi konsep.

e. Tidak paham konsep pada materi pertidaksamaan nilai mutlak, pecahan dan irasional. Dapat dilihat pada gambar 5:

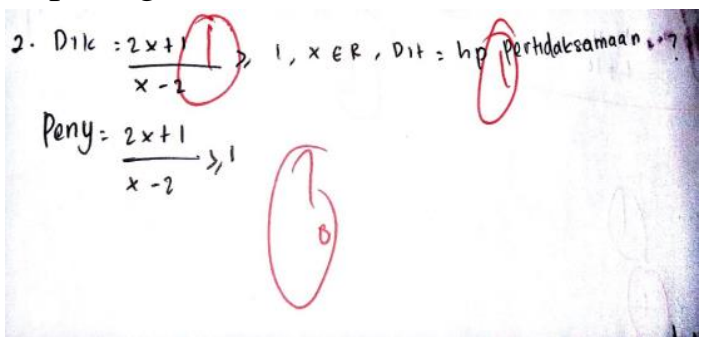

Gambar 5. Jawaban tes diagnostik P4 Nomor 2

Berdasarkan gambar 5 dapat dikatakan bahwa P4 benar-benar tidak memahami konsep karena dilihat dari jawabannya P4 tidak mampu menyelesaikan soal secara baik dan benar.

Tabel 1. Persentase Paham Konsep, Miskonsepsi dan Tidak Paham Konsep Berdasarkan Nomor Soal

\begin{tabular}{|c|c|c|c|c|c|c|}
\hline \multirow{2}{*}{$\begin{array}{c}\text { No. } \\
\text { Soal }\end{array}$} & \multicolumn{6}{|c|}{ Kriteria } \\
\cline { 2 - 7 } & Paham Konsep & \multicolumn{2}{|c|}{ Miskonsepsi } & \multicolumn{2}{|c|}{ Tidak Paham } \\
\cline { 2 - 7 } & $\mathrm{F}$ & $\%$ & $\mathrm{~F}$ & $\%$ & $\mathrm{~F}$ & $\%$ \\
\hline 1 & 0 & 0.00 & 20 & 52.63 & 18 & 47.37 \\
\hline 2 & 5 & 13.16 & 3 & 7.89 & 30 & 78.95 \\
\hline 3 & 4 & 10.53 & 22 & 57.89 & 12 & 31.58 \\
\hline 4 & 11 & 28.95 & 13 & 34.21 & 14 & 36.84 \\
\hline 5 & 20 & 52.63 & 8 & 21.05 & 10 & 26.32 \\
\hline 6 & 2 & 5.26 & 10 & 26.32 & 26 & 68.42 \\
\hline 7 & 0 & 0.00 & 9 & 23.68 & 29 & 76.32 \\
\hline 8 & 34 & 89.47 & 3 & 7.89 & 1 & 2.63 \\
\hline 9 & 28 & 73.68 & 9 & 23.68 & 1 & 2.63 \\
\hline 10 & 9 & 23.68 & 25 & 65.79 & 4 & 10.53 \\
\hline Jumlah & 113 & 297.37 & 122 & 321.05 & 145 & 381.6 \\
\hline $\begin{array}{c}\text { Rata- } \\
\text { rata }\end{array}$ & 11.30 & 29.74 & 12.20 & 32.11 & 14.50 & 38.16 \\
\hline
\end{tabular}

Berdasarkan tabel di atas persentase siswa yang paham konsep dari hasil penelitian ini sebesar $29,74 \%$, persentase siswa yang mengalami miskonsepsi sebesar $32,11 \%$ dan persentase siswa yang tidak paham konsep sebesar 38,16\%. Dari tabel di atas dapat dilihat bahwa persentase siswa yang paham konsep, miskonsepsi dan tidak paham konsep pada setiap nomor soal sangat beragam, maka dari itu untuk lebih jelasnya dapat dilihat pada grafik perbandingan paham konsep, miskonsepsi dan tidak paham konsep berikut ini:

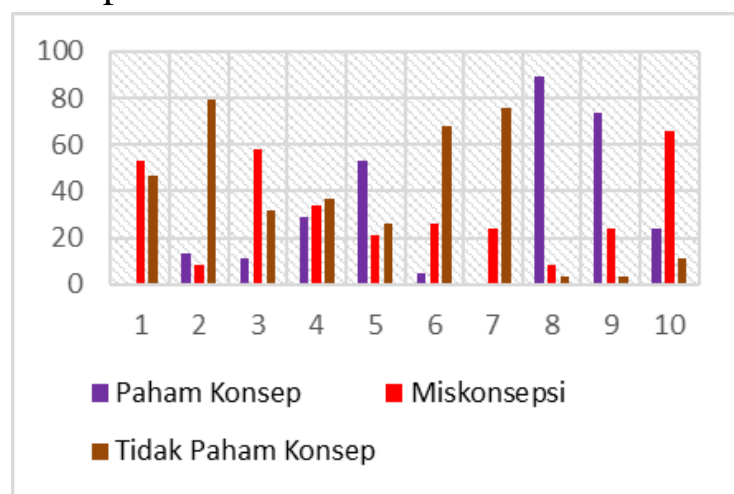

Gambar 6. Grafik Perbandingan Persentase Paham Konsep, Miskonsepsi dan Tidak Paham Konsep

Dari gambar grafik di atas dapat dilihat bahwa persentase miskonsepsi pada setiap nomor soal berbeda-beda. Rata-rata persentase miskonsepsi yang terjadi paling tinggi adalah pada sub pokok materi persamaan dan pertidaksamaan linear nilai mutlak satu variabel dengan indikator pemahaman konsep (1) mendefinisikan konsep secara verbal dan tulisan dan (6) mengidentifikasi sifat-sifat suatu konsep dan mengenal syarat yang menentukan suatu konsep. Hal ini disebabkan banyaknya siswa belum memahami konsep nilai mutak utamanya pada memahami sifat-sifat untuk menentukan penyelesaian nilai mutlak. Sedangkan 
untuk materi program linear sebagian besar peserta tes menjawab benar pada setiap soal yang ada sebab untuk materi ini konsep yang harus diterapkan kebanyakan siswa sudah memahaminya dan konsepnya juga tidak banyak, materi program linear juga sudah dipelajari berulang-berulang, jadi dapat memudahkan siswa untuk mempelajarinya dan mengulangnya kembali.

\subsection{Pembahasan}

Penelitian ini mengembangkan instrumen tes berupa tes diagnostik berbentuk uraian yang telah melalui serangkaian fase model Plomp yakni mulai dari tahap pengkajian awal (preliminary investigation phase), tahap perancangan (desain phase), tahap realisasi/konstruksi

(realization/construction phase), serta tahap tes, evaluasi dan revisi (test, evaluation and revision phase). Sehingga menghasilkan sebuah produk yaitu instrumen tes diagnostik berbentuk uraian berjumlah 10 butir soal. Sebelum proses pengembangan dilakukan, telah ditetapkan suatu kriteria kualitas instrumen tes untuk melihat sejauh mana keberhasilan produk yang dihasilkan.

Berdasarkan hasil yang diperoleh pada tahap prototyping dan field tes, yaitu penilaian ahli dan validasi serta uji coba lapangan, instrumen tes yang dihasilkan mencapai kriteria yang telah ditetapkan, yaitu valid dan reliabel. Sedangkan tingkat kesukaran instrumen tes dan daya pembeda instrumen tes secara keseluruhan sudah baik. Instrumen tes secara umum dinyatakan valid dengan interpretasi tinggi yakni dengan melihat nilai CVI yang dihasilkan adalah 1 dengan kategori sangat sesuai. Reliabilitas instrumen tes secara umum dinyatakan reliabel karena berdasarkan analisis instrumen tes reliabilitas yang dilakukan dengan bantuan SPSS Statistic Ver.20 diperoleh nilai reliabilitas sebesar 0,754 dengan interpretasi yang tinggi. Artinya instrumen tes diagnostik berbentuk uraian ini reliabel atau dapat dipercaya untuk digunakan dalam mengidentifikasi tingkat pemahaman konsep matematika siswa artinya walaupun digunakan secara berulangulang hasilnya akan tetap sama atau dapat dipercaya. Hal ini sejalan dengan teori yang diungkapkan oleh Thorndike dan Hagen bahwa reliabilitas berhubungan dengan akurasi instrumen dalam mengukur apa yang hendak diukur, kecermatan hasil ukur dan seberapa akurat seandainya dilakukan pengukuran ulang.

Angket respon siswa pada instrumen tes diagnostik berbentuk uraian pada uji coba lapangan diperoleh rata-rata respon positif siswa adalah $84,2 \%$ dan rata-rata respon negatif siswa adalah $15,8 \%$. Sehinga angket respon siswa memenuhi kriteria "tercapai" dan tidak ada perbaikan/revisi terhadap instrumen tes yang akan dikembangkan karena lebih dari $50 \%$ siswa yang memberikan respon positif.

Tingkat kesukaran instrumen tes dilihat dari indeks masing-masing item soal. Sesuai dengan pernyataan Allen dan Yen tingkat kesukaran tes didefinisikan sebagai proporsi yang menjawab butir itu dengan benar. Apabila butir tes dijawab dengan benar oleh semua peserta tes, berarti butir tes tersebut sangat mudah begitupula 
sebaliknya. Suatu soal tes hendaknya tidak terlalu sukar dan tidak terlalu mudah. Berdasarkan analisis di atas rata-rata tingkat kesukaran soal yaitu 0,56 dengan kategori sedang, artinya soal yang telah diujikan tidak terlalu mudah dan tidak terlalu sukar. Sehingga secara keseluruhan tingkat kesukaran instrumen tes diagnostik berbentuk uraian sudah baik.

Daya pembeda instrumen tes berdasarkan kriteria soal yang baik terdapat pada rentang $0,20<\mathrm{Dp} \leq 0,40$. Berdasarkan hasil daya pembeda maka $40 \%$ soal memiliki daya pembeda dengan kategori baik. $40 \%$ soal memiliki daya pembeda dengan kategori cukup dan $20 \%$ soal memiliki daya pembeda dengan kategori jelek. Daya pembeda yang sesuai kriteria yaitu daya pembeda dengan kategori cukup dan baik, hasil analisis tersebut menunjukkan $80 \%$ dari soal sesuai dengan kriteria daya pembeda, dengan rata-rata daya pembeda yaitu 0,34 yang berada pada kategori cukup. Berdasarkan hasil tersebut artinya instrumen tes yang dikembangkan cukup mampu membedakan siswa yang berkemampuan tinggi dan siswa yang berkemampuan rendah. Hal ini sejalan dengan teori tes klasik yang menyatakan bahwa jika dalam suatu kelompok peserta uji tes dibagi menjadi dua kelompok, kelompok $\mathrm{X}$ dan $\mathrm{Y}$ maka daya beda soal adalah kemampuan soal itu membedakan antara kelompok X dan Y.

Berdasarkan hasil data tes diagnostik berbentuk uraian untuk mengidentifikasi pemahaman konsep siswa, dapat diketahui bahwa jumlah siswa yang termasuk dalam kategori paham konsep $29,74 \%$, persentase siswa yang mengalami miskonsepsi sebesar $32,11 \%$ dan persentase siswa yang tidak paham konsep sebesar 38,16\%. Dari hasil tes dapat diketahui bahwa kemampuan siswa dalam memahami konsep rata-rata hampir sama terbukti dari persentase peserta tes yang paham konsep, miskonsepsi dan tidak paham konsep ketiganya tidak memiliki persentase yang tidak begitu jauh karena berada pada persentase $30 \%$, namun ada beberapa siswa yang mengalami miskonsepsi dan tidak paham konsep terhadap butir soal atau materi tertentu. Hasil tes tersebut menunjukkan bahwa tes diagnostik yang dikembangkan mampu mengidentifikasi tingkat pemahaman konsep siswa, dapat dilihat dari berapa siswa yang teridentiikasi miskonsepsi, tidak paham konsep ataupun paham konsep. Hal ini sejalan dengan pendapat Brueckner dan Melby yang mengemukakan bahwa tes diagnostik digunakan untuk menemukan elemenelemen dalam suatu mata pelajaran yang mempunyai kelemahan-kelemahan khusus dan menyediakan alat untuk menemukan penyebab kekurangan tersebut. Sehingga dari tes diagnostik ini mampu mengidentifikasi siswa yang mengalami miskonsepsi, paham konsep dan tidak paham konsep.

Hasil analisis pemahaman konsep siswa menunjukkan bahwa butir soal yang paling banyak persentase miskonsepsinya adalah soal nomor 10 dengan persentase miskonsepsi sebesar $65,79 \%$ atau sebanyak 25 dari 38 peserta tes yang mengalami miskonsepsi pada soal ini, sebab dari analisis jawaban siswa kebanyakan hanya mengarang jawaban dalam menyelesaikan soal tersebut. Sedangkan 
materi yang paling tinggi persentase tidak paham konsepnya adalah pada materi pertidaksamaan nilai mutlak, pecahan dan irasional serta fungsi dari butir soal nomor 2 dan 7 yaitu sebesar masing-masing siswa yang tidak paham konsep berturut-turut sejumlah 30 dan 29 dari 38 peserta tes tidak paham konsep pada materi tersebut. Materi ini memang terbilang cukup sulit pada pengaplikasian konsepnya, siswa seringkali belum paham dalam menentukan soal cerita serta siswa bingung menentukan daerah domain, kodomain dan range pada materi fungsi, sehingga sulit untuk menentukan rumus fungsinya. Banyaknya miskonsepsi dan tidak paham konsep pada materi ini membuktikan bahwa siswa tidak memahami konsep yang diajarkan. Berdasarkan hasil observasi dan wawancara didapatkan bahwa miskonsepsi pada konsep ini berasal dari metode pembelajaran yang diterapkan oleh guru dan buku referensi luar sekolah. Miskonsepsi banyak terjadi juga bisa dikarenakan guru seringkali serius dalam mengajar sehingga perhatian terhadap peserta didik menjadi berkurang meskipun guru mengetahui betul konsep yang diajarkan.

\section{KESIMPULAN}

Instrumen tes yang dikembangkan secara keseluruhan termasuk dalam kualitas yang baik dilihat dari validitas, reliabilitas, daya pembeda serta tingkat kesukarannya. Tes yang dikembangkan memiliki indeks validitas isi (CVI) sebesar 1,00 dan reliabilitas dengan kategori tinggi sebesar 0,75. Berdasarkan hasil data tes diagnostik berbentuk uraian untuk mengidentifikasi pemahaman konsep siswa, dapat diketahui bahwa jumlah siswa yang termasuk dalam kategori paham konsep $29,74 \%$, persentase siswa yang mengalami miskonsepsi sebesar $32,11 \%$ dan persentase siswa yang tidak paham konsep sebesar 38,16\%. Dari hasil tes dapat diketahui bahwa kemampuan siswa dalam memahami konsep hampir seimbang terbukti dari persentase peserta tes yang cenderung hampir sama antara paham konsep, miskonsepsi dan tidak paham konsep, namun disamping itu tidak dapat terhindarkan bahwa lebih banyak persentase siswa yang mengalami miskonsepsi dan tidak paham konsep terhadap butir soal atau materi tertentu. Hasil analisis pemahaman konsep siswa menunjukkan bahwa butir soal yang paling banyak persentase miskonsepsinya adalah soal nomor 10 dengan persentase miskonsepsi sebesar $65,79 \%$. Sedangkan butir soal dengan persentase tidak paham konsep tertinggi ada soal nomor 7 sebab pada soal ini sebesar 76,32\%. Berdasarkan hasil analisis miskonsepsi dinyatakan bahwa materi yang paling tinggi persentase miskonsepsinya adalah pada materi persamaan dan pertidaksamaan linear nilai mutlak satu variable yaitu sebesar $52,63 \%$.

\section{DAFTAR PUSTAKA}

Hamzah, A. (2014). Evaluasi Pembelajaran Matematika. Cet. II; Jakarta: Rajawali Pres.

Kurnia, S., Y, (2006.) 'Penyusunan Tes Diagnostik Fisika Pokok Bahasan Kinematika Gerak Lurus untuk Siswa Kelas X SMA di Kota Semarang Tahun Pelajaran 2005/2006", (Skripsi Sarjana, 
Fakultas Matematika dan Ilmu Pengetahuan Alam, Semarang).

Mania, S. (2018) Diagnostic Test Instrument of Twi-Tier Multiple Choices To Identify Mathematic Concept Understanding. Journal of Physics: Conference Series, Volume 1114

Mutmainna, D. (2018) "Pengembangan Instrumen Tes Diagnostik Pilihan Ganda Dua Tingkat untuk Mengidentifikasi Pemahaman Konsep Matematika", MaPan : Jurnal Matematika dan Pembelajaran 6, No. 1

Murizal, A. (2012). "Pemahaman Konsep Matematis dan Model Pembelajaran Quantum Teaching. Jurnal Pendidikan Matematika. 1(1),

Rahayu, S. (2015). "Pengembangan Tes Diagnostik Pilihan Ganda Dua Tingkat untuk Mengidentifikasi
Miskonsepsi pada Konsep Gerak Dua Dimensi ", Skripsi Sarjana, Program Studi Pendidikan Fisika UIN Syarif Hidayatullah Jakarta.

Rawa, N., R. (2016). Pengembangan Perangkat Pembelajaran Berbasis Model Learning Cycle-7e pada Materi Trigonometri untuk Meningkatkan Kemampuan Pemahaman konsep Siswa. Jurnal Pendidikan. 1(6),

Sunismi. (2012). Membangun Item Tes Diagnostik untuk Mengungkap Miskonsepsi Siswa pada Materi Bentuk Aljabar. Jurnal Sarjana, FKIP Universitas Islam Malang,

Suwarto. (2010). Mengungkap Karakteristik Tes Uraian. 19(2),

Suwarto. (2013). Pengembangan Tes Diagnostik dalam Pembelajaran. Yogyakarta: Pustaka Pelajar. 